\title{
SiM
}

\section{Sustaining Ecosystem Services From Private Lands in California: The Role of the Landowner}

\author{
By Shasta Ferranto, Lynn Huntsinger, and Maggi Kelly
}

\section{On the Ground}

- California landownerships are changing-becoming smaller and more amenity-driven, with important implications for ecosystem service production.

- Residence on the property, larger property size, source of income from the land, having a longterm outlook, and using an advisory service are associated with landowner management for ecosystem services for the owner and for society.

- Advisory services like Cooperative Extension and the Natural Resources Conservation Service, as well as private consultants and professional organizations, have an important role in the future of ecosystem service production.

Keywords: land tenure, fragmentation, landowner behavior, advisory services, Cooperative Extension, income, working landscapes, property size, longterm outlook, California rangelands.

Rangelands 36(5):44-51

doi: 10.2111/RANGELANDS-D-14-00023.1

(C) 2014 The Society for Range Management

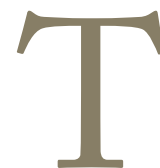

he term "ecosystem services" was coined to express the value of natural systems to human wellbeing - a straightforward definition is "the benefits people obtain from ecosystems." ${ }^{1}$ Achieving sustainability and maintaining flows of ecosystem services in California requires attention to private lands and their unique management constraints and opportunities. Forty percent, 13 million ha, of California's forests and rangelands are privately owned. ${ }^{2}$ Deserts and forests are mostly in government ownership, while the state's Mediterranean rangelands are largely in private hands; for example, more than $80 \%$ of hardwood rangelands and annual grasslands are in private ownership. ${ }^{3}$
In addition, many ecosystem services are a result of social ecological systems that include livestock grazing and forestry. ${ }^{4}$ Landowner participation in sustaining ecosystem services means conservation initiatives need to build on landowner management objectives, practices, and goals. Moreover, private landscapes are often fragmented into multiple parcels where decisions are made by numerous individuals with diverse goals, and this fragmentation is increasing. These trends influence the capacity of the ecosystem to provide ecosystem services, ${ }^{5}$ and increase the need for outreach and cooperative management.

\section{The Landowner Profile Is Changing}

Prior to 1950, rural land use in the United States was typically agriculture. From 1950 to 1970 rural residents began moving to urban centers for economic and social opportunities. Migration slowed in the 1980s, and then picked back up again in the 1990s in what is commonly referred to as the "rural rebound," an in-migration of new residents into rural America largely driven by those seeking a rural lifestyle. Between 1970 and 2010 approximately 27,114 ha/year of forest and rangeland were converted to urban development (defined as more than 1 house/ $2 \mathrm{ha}$ ) and 47,000 ha/year were converted to exurban development (more than 1 house per 8 acres). Since 1950 there has been a five-fold increase in exurban development. ${ }^{6}$ In California, between 1940 and 2000, 10\% of private forests and rangelands were fragmented into areas with more than 1 house/ $8 \mathrm{ha}^{2}$ These trends are expected to continue with almost 2 million ha of forest and rangeland considered at medium to high risk for future development. ${ }^{2}$ Many forest and rangeland owners report being approached by speculators to sell their land for development. ${ }^{7}$

The rural rebound brought changes to rural communities, particularly in amenity-rich regions. New landowners include retirees, younger people seeking a slower pace of life, professionals who can commute or work remotely from urban areas, and seasonal homeowners. A longitudinal study based on a 1985 survey of California hardwood rangeland landowners 
with more than 8 ha of property, repeated in 1993 and 2004, showed that between 1985 and 2004 the number of landowners involved in production of crops or livestock declined, but the proportion of landowners who own their land primarily for amenities such as natural beauty, recreation, and lifestyle benefits significantly increased. ${ }^{8}$ Community norms and practices associated with production declined, and norms and values associated with amenity enjoyment increased. In Nevada County, a former mining and ranching community in the Sierra Nevada foothills, efforts in participatory planning were derailed by the conflicting landscape ideologies between amenity-driven in-migrants and long-time residents with ties to production. ${ }^{9}$ This trend has been observed in rural areas throughout the United States and in other parts of the world. ${ }^{10}$

As ecosystems become increasingly fragmented, ecosystem service provision is altered. The ecological impacts include decreased biodiversity, fragmentation of forests and wildlife habitat, and an inability to conduct management like prescribed burning to prevent wildfires. ${ }^{11}$ New landowners may manage for habitat types other than the open grassland and savanna habitats typical of ranched landscapes. ${ }^{12}$ Similar processes occur in forested landscapes. ${ }^{13}$

Landowners play a critical role in achieving environmental goals. Many of the environmental challenges facing California can only be addressed through landscape-scale management solutions. As property sizes decrease, management will need to engage more landowners to cover the same amount of area.

Here we review publications from recent surveys of forest and rangeland landowners in California (Table 1), focusing on five factors that often show up as strongly related to landowner choices. The data from one survey, a 2008 statewide survey of forest and rangeland landowners ${ }^{7}$ with more than $1.2 \mathrm{ha}$, are then analyzed to specifically examine the relationship of the five factors with landowner desire to produce ecosystem services for personal use and for society, and with landowner practices that produce such ecosystem services. The factors analyzed are how much of the year the landowner resides on the property; how important income from the land is to the landowner; what the owner's long-term plans for the property are; whether the owner has a larger property-larger than 40 ha in this case; and whether or not the landowner has gotten advice from an advisory agency. This is by no means a comprehensive list of things that are strongly related to landowner behavior, but a selection of factors that have shown up repeatedly as important in diverse landowner surveys, and they are present among the variables in the 2008 survey results, enabling us to carry out the analysis.

\section{The Landowner's Relationship to the Land: Residence on the Property}

Most California rangeland landowners live on their properties year round, with $60 \%$ of forest and rangeland landowners surveyed in 2008 reporting that their primary residence was on the property. For other owners, about half used the property as a vacation or second home. ${ }^{7}$ A 1985 survey of California hardwood rangeland landowners showed that residence on hardwood rangeland properties was related to landowner practices. ${ }^{14}$ The longitudinal study found that the rate of absentee ownership did not change significantly from 1985 to 2004 , ranging from $22 \%$ to $25 \%$, nor did average length of ownership overall, ranging from 35 to 44 years. ${ }^{8}$

While residence on the property is not related to property size, length of ownership is. The 2008 survey of forest and rangeland owners found an average length of ownership of 31 years overall, but landowners with properties of 1 to 3 ha had owned their land an average of around 19 years, while those with more than 200 ha had an average length of ownership of approximately 60 years. ${ }^{7}$

\section{Size Matters}

Property size has been shown in numerous studies to have a strong connection to landowner activities and to correlate with motivations. ${ }^{78}$ In the 2008 survey, owners of smaller properties responded that lifestyle factors were an important reason to own their land more often than did owners of larger properties. ${ }^{7}$ Owners of large properties (202 or more ha) were more likely to use their land for income production than owners of smaller properties, and more likely to carry out or be interested in environmental improvements. More often than other landowners, they considered "family tradition or business" and "income source" important reasons for owning their land, and planned to pass their land on to their children. ${ }^{7}$ They were also more likely to receive advice about land management from agencies or programs. ${ }^{15}$ In a 2013 study of California ranchers, researchers listed property size as a major factor associated with landowner behavior based on a literature review, and their survey confirmed it. ${ }^{16}$

An alternate analysis ${ }^{17}$ of the 2008 survey data ${ }^{7}$ investigated whether owners with 8 ha or more that produce livestock or timber appreciate biodiversity and ecosystem services in different ways than purely residential owners, and how valuing one kind of ecosystem service might be related to valuing others. Both specific uses and management practices and underlying attitudes and motivations towards biodiversity and ecosystem services were assessed. Correlation analysis showed that valuing livestock, timber, crops, and housing is associated, forming a "bundle" of ecosystem services supported by many landowners. Another bundle of ecosystem services supported by many landowners includes recreation, hunting and fishing, wildlife habitat, and fire prevention. Livestock and timber producers were more likely to ally with the first bundle and purely residential owners, who tended to have smaller properties, allied to the second. Results further confirmed that cultural ecosystem services and quality of life are among the primary motivations for forest and rangeland ownership for owners of all property sizes and lifestyles. To live near natural beauty was the most important motive for both landowner groups. Producers were 
Table 1. Recent California forest and rangeland management surveys reviewed in this paper

\begin{tabular}{|c|c|c|}
\hline Year of survey & Citation & Surveyed group \\
\hline 1985 & $\begin{array}{l}\text { FORTMANN, L. P., AND L. HUNTSINGER. } 1989 \text {. The effects of non-met- } \\
\text { ropolitan population growth on resource management. Society and } \\
\text { Natural Resources } 2(1): 9-22 \text {. }\end{array}$ & $\begin{array}{l}\text { Hardwood rangeland landown- } \\
\text { ers statewide }\end{array}$ \\
\hline 1985-2004 & $\begin{array}{l}\text { HUNTSINGER L., M. JOHNSON, M. STAFFORD, AND J. FRIED. } 2010 . \\
\text { Hardwood rangeland landowners in California from } 1985 \text { to } 2004 \text { : } \\
\text { Production, ecosystem services, and permanence. Rangeland } \\
\text { Ecology \& Management 63(3):324-334. }\end{array}$ & $\begin{array}{l}\text { Hardwood rangeland landown- } \\
\text { ers statewide, properties larger } \\
\text { than } 8 \text { ha }\end{array}$ \\
\hline 2008 & $\begin{array}{l}\text { FERRANTO, S., L. HUNTSINGER, C. GETZ, G. NAKAMURA, W. STEWART, } \\
\text { S. DRILL, Y. VALACHOVIC, M. DELASAUX, AND M. KELLY. 2011. Forest } \\
\text { and rangeland owners value land for natural amenities and as } \\
\text { financial investment. California Agriculture 65(4):184-191. } \\
\text { FERRANTO, S., L. HUNTSINGER, W. STEWART, C. GETZ, G. NAKAMURA, } \\
\text { AND N. M. KELLY. 2012. Consider the source: the impact of media } \\
\text { and authority in outreach to private forest and rangeland owners. } \\
\text { Journal of Environmental Management } 97: 131-140 \text {. } \\
\text { PLIENINGER, T., S. FERRANTO, L. HuNTSINGER, N. M. KELLY, AND C. } \\
\text { GETZ. 2012. Appreciation, use, and management of biodiversity } \\
\text { and ecosystem services in California's working landscapes. Envi- } \\
\text { ronmental Management 50(3):427-440. } \\
\text { FERRANTO, S., L. HUNTSINGER, C. GETZ, M. LAHIFF, W. STEWART, G. } \\
\text { NAKAMURA, AND N. M. KELLY. 2013. Management without borders? A } \\
\text { survey of landowner practices and attitudes towards cross-bound- } \\
\text { ary cooperation. Society and Natural Resources } 26: 1082-1100 \text {. }\end{array}$ & $\begin{array}{l}\text { Forest and rangeland landown- } \\
\text { ers statewide ( } 10 \text { counties, at } \\
\text { least one from each bioregion), } \\
\text { properties larger than } 1.2 \text { ha }\end{array}$ \\
\hline 2010 & $\begin{array}{l}\text { CHEATUM, M. F., A. P. CASEY, AND B. PARKHURST. 2011. Payments for } \\
\text { ecosystem Services: A California rancher perspective. Washing- } \\
\text { ton, DC, USA: Nicholas Institute for Environmental Policy Solu- } \\
\text { tions, Duke University. } 47 \text { p. }\end{array}$ & $\begin{array}{l}\text { California Cattlemen's Associa- } \\
\text { tion mailing list ranchers }\end{array}$ \\
\hline 2011 & $\begin{array}{l}\text { LUBELL, M. N., AND B. B. CUTTS, L. M. ROCHE, M. HAMILTON, J. D. } \\
\text { DERNER, E. KACHERGIS, AND K. W. TATE. Conservation program par- } \\
\text { ticipation and adaptive rangeland decision-making. 2013. Range- } \\
\text { land Ecology \& Management 66(6):609-620. }\end{array}$ & $\begin{array}{l}\text { California Cattlemen's Associa- } \\
\text { tion mailing list ranchers }\end{array}$ \\
\hline
\end{tabular}

much more active in management for habitat improvement and other environmental goals than residential owners.

\section{Where's the Money?}

The majority of landowners in the landowner surveys earned little to no income from the land, and those that did still considered amenities an important reason for owning the land. In one analysis of the 2008 data, landowners were grouped into four typologies according to ownership motivations. ${ }^{11}$ The groups were distinguished by landowner motives centered on rural lifestyles, working landscapes, natural amenities, or financial investment. All but the financial-investment-oriented group considered living near natural beauty the most important or second most important reason for owning their land. ${ }^{11}$ Those with larger properties were also far more likely to consider income an important reason for owning their land, with more than $70 \%$ of those with more than 200 ha, compared to less than $20 \%$ of those with 1 to 9 ha, responding that income from the land was important to them. All groups considered land appreciation an important motive for owning their land.

The longitudinal study revealed a steady, significant decline from $27 \%$ of owners getting most of their income from ranching in 1985 , to $14 \%$ doing so in $2004 .{ }^{8}$ In addition, in 1985 , $68 \%$ of owners sold some products from their land, while in 2004, 47\% did. The literature review for the 2013 study of ranchers identified number of sources of off-ranch income as an important factor related to landowner behav- 
ior. ${ }^{16}$ In the 2008 survey of forest and rangeland landowners, which included smaller properties than the other studies, about one-third of the owners earned income from timber or livestock. Studies of California rural landowners always show that owners of larger properties are more likely to produce and market livestock or timber. Overall, in the 2008 study, about $35 \%$ of owners stated that earning an income from the land was important or very important.

\section{Long- or Short-Term Outlook}

Considering conservation easement on the property-selling or donating the development rights - can be interpreted as an interest on the part of the landowner in managing for the long term. In the 2004 survey, this was found to be associated with the environmentally positive action of planting oaks in hardwood rangelands. ${ }^{8}$ The 2008 survey showed that $79 \%$ of landowners with more than 200 ha planned to pass on their land to their children, while $48 \%$ of those with 1 to 4 ha did. ${ }^{7}$ Based on a review of the literature, the authors of the 2013 rancher study hypothesized long-term outlook to be an important factor related to landowner behavior. They used "having a succession plan" and "number of generations ranching" as indicators of a long-term outlook for the land and found that this was related to participation in and awareness of conservation easement programs. ${ }^{16}$

\section{Getting Help From Advisory Services and Neighbors}

Landowners reported that a number of organizations provided them with land management advice, but no individual organization reached more than $30 \%$ of forest and rangeland owners, and all advisory organizations together reached less than $60 \%$ of landowners. ${ }^{15}$ Owners of large properties $(>200$ ha) were substantially more likely to have received land management advice than owners of smaller properties, and from a broader group of organizations.

The perceived quality of the advice landowners received varied depending on where it came from. ${ }^{15}$ The most highly ranked land management advice came from private consultants, industry associations, and advisory organizations such as Cooperative Extension. Landowners viewed advice more cautiously when it came from organizations that have regulatory authority or control over use of natural resources, with the perhaps wise exception of county fire departments. The lowest perceived quality of advice ratings went to wildlife agencies with a strong regulation and enforcement role. A 2010 California rancher survey found willingness to be paid to produce ecosystem services, and how much landowners wanted to be paid, depended on the "payee." The highest price and lowest willingness was reserved for regulatory agencies. ${ }^{18}$ These results suggest that advisory organizations are in a strong position to influence private land management. As an example, surveys of hardwood rangeland landowners showed that those receiving advice from Cooperative Extension were more likely to plant oaks. ${ }^{8}$
Landowners in the 2008 survey generally said that they supported the idea of working with neighbors and agencies to accomplish conservation goals. ${ }^{11}$ Analysis of landowners as grouped by ownership motives revealed that all groups were willing to cooperate for pest and disease control, fire hazard reduction, and wildlife conservation, but their degree of willingness differed by group, whom they were expected to cooperate with, and the natural resource problem addressed. All were more willing to cooperate with neighbors and local groups than with state and federal agencies. Landowners were also more willing to cooperate to attack problems that are a direct threat to property and well-being, like fire hazard. This suggests that projects that offer obvious and direct benefits to landowners will be more likely to engender cooperation. Landowners who owned their land primarily for natural amenities were the most supportive of cooperative efforts, followed by working landscape owners, rural lifestyle owners, and finally financial investment owners. ${ }^{11}$

\section{Analysis of Selected Landowner Characteristics Associated With Production of Ecosystem Services}

Overall, research in California has shown strong relationships between landowner motives and actions, and type of residency, property size, income production goals, technical advice, and long-term planning. To look specifically at the relationship between these factors and ecosystem service production, a new analysis of data from the 2008 survey was conducted. As described in Ferranto et al (2011) in detail,, a mail questionnaire was sent to forest and rangeland owners on parcels greater than 1.2 ha in size from 10 forest and/or rangeland counties in California, including a minimum of one county from each of six California bioregions defined by the state for natural resources assessment purposes. ${ }^{2}$ Using a statewide land parcel database created in 2003 for the state's Forest and Range Assessment, ${ }^{3}$ a randomized sample of landowners, stratified by property size, was generated by county. Forest and rangeland definitions included all forest, woodland, grassland, and shrub vegetation types. The survey was mailed to 1,730 landowners in the spring of 2008 following a modified version of the Dillman Total Design Method ${ }^{19}$ and after adjusting for undeliverable questionnaires and questionnaires sent to nonforest or rangeland owners, the final adjusted response rate was $42.5 \%$. All data analysis was done in SPSS 17.0 statistical software, weighted proportionally to sampling intensity to adjust for the stratification. Response choices were based on a scale from 1 to 5, ranging from "not at all important" (value $=1$ ) to "highly important" (value $=5$ ). Specific analyses are described in detail in the cited papers.

To look specifically at the relationship between ecosystem service production and selected variables found in previous studies to be associated with landowner behavior, five variables were selected from those in the survey: living on the land for more than 1 month a year (residence status), earning income is an important or very important goal, having a 


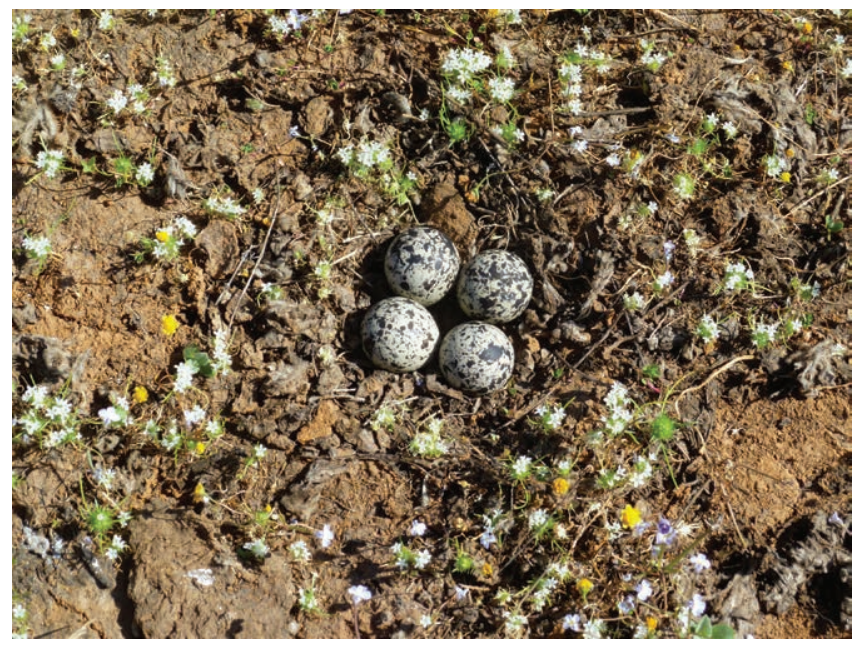

Figure 1. Killdeer eggs on rangeland.

long-term outlook for the land (planning to pass land on to children), a property size of over $40 \mathrm{ha}$, and receiving technical advice from a natural resources advisory agency. Scores built of summed responses to survey questions were created for the dependent variables (Table 1). The first two scores are from a question about landowner practices that produce ecosystem services that benefit the landowner and society overall (planting native species, organic production, water quality improvement, improving wildlife habitat, and removing exotics). Responses are summed in the first score (1) for carrying out a practice, and in the second (2), for planning to carry out a practice. Landowner goals for management of ecosystem services were also assessed with two indices developed from summing landowner responses to questions about the importance of various goals as a reason to own property: Score (3) is for having the goal of consuming ecosystem services on their land (wanting to live near natural beauty, to enjoy recreation); and score (4) is for having the goal of producing ecosystem services also of benefit to society (the goal of protecting the environment, preserving open space or natural resources). These responses ranged from 1 to 5 for "not at all important" as a goal to "highly important" as a goal. The impact the independent variables had on landowner goals and management for provision of ecosystem services was analyzed using a simple $t$ test (Table 2).

\section{Results}

There were high rates of management for ecosystem services among all landowners. More than half (55\%) managed for improving wildlife habitat, while a third (34\%) thought they might in the future. Similarly, 53\% managed for water quality improvement while another $35 \%$ thought they might in the future. More than a third used organic production (34\%), another $48 \%$ thought it likely they would use it in the future, while 39\% planted native plants and $45 \%$ thought they might in the future. Nearly half, $42 \%$, removed exotic plants and $35 \%$ thought they might in the future.
Most of the selected landowner characteristics had a significantly positive relationship with managing for ecosystem services and with ecosystem services as a goal of landownership (Table 2). Living on the land, having a goal of earning income, planning to pass the land on to your children, having more than $40 \mathrm{ha}$, and getting technical advice from a natural resources advisory agency all are indicators of landowner goals and practices that produce ecosystem services that benefit the landowner in the enjoyment of the property, and that are also likely to be generally positive for the larger public. While importance of income and having more than 40 ha were not significantly related to the goal of producing ecosystem services for the owner, they were linked to the goal of producing services believed to have benefits to society, and to practices that produced ecosystem services of value to the owner and to the broader public.

\section{How Can Ecosystem Service Production Be Encouraged?}

It is apparent that many landowners have a goal of managing for ecosystem services, for their own benefit and for the benefit of society and/or the environment. What kinds of programs seeking to maintain rangeland ecosystem services build on these landowner goals?

Ranchers prefer incentive programs, or payment for environmental services programs, to regulations as a policy intervention to encourage production of ecosystem services. More than two-thirds of California ranchers surveyed in 2010 were receptive to the idea of being rewarded monetarily "to improve the quantity and/or quality of environmental benefits that their land provides to society," even though many were unfamiliar with the specific term "ecosystem services." ${ }^{18}$ Provision of wildlife habitat was what ranchers stated they would like to market or be rewarded for producing, but there was also considerable willingness to restore native plants, improve water quality, and increase carbon storage.

The 2008 survey revealed that some forest and rangeland landowners are already enrolled in payment for ecosystem services (PES) programs providing financial and technical assistance in exchange for environmentally friendly practices or outcomes. ${ }^{7}$ These include the federal Environmental Quality Incentives Program (EQIP-8\% of landowners), the Wildlife Habitat Incentives Program (WHIP-4\% of landowners) and the State's California Forest Improvement Program (CFIP$7 \%$ of landowners). The California Land Conservation Act or Williamson Act, which exchanges tax breaks for a commitment to remain in agricultural land use, enrolled about $19 \%$ of landowners and another $16 \%$ were in a Timberland Production Zone providing tax breaks for maintaining land in timber production. About $6 \%$ of landowners had conservation easements in 2008, held by 23 different land trusts, and another $33 \%$ were receptive to the idea of selling one-demand outstrips the funding for easements in California. Conservation easements are a market for ecosystem services, with willing sellers and buyers and a negotiated price. Organic certification, with 3\% 


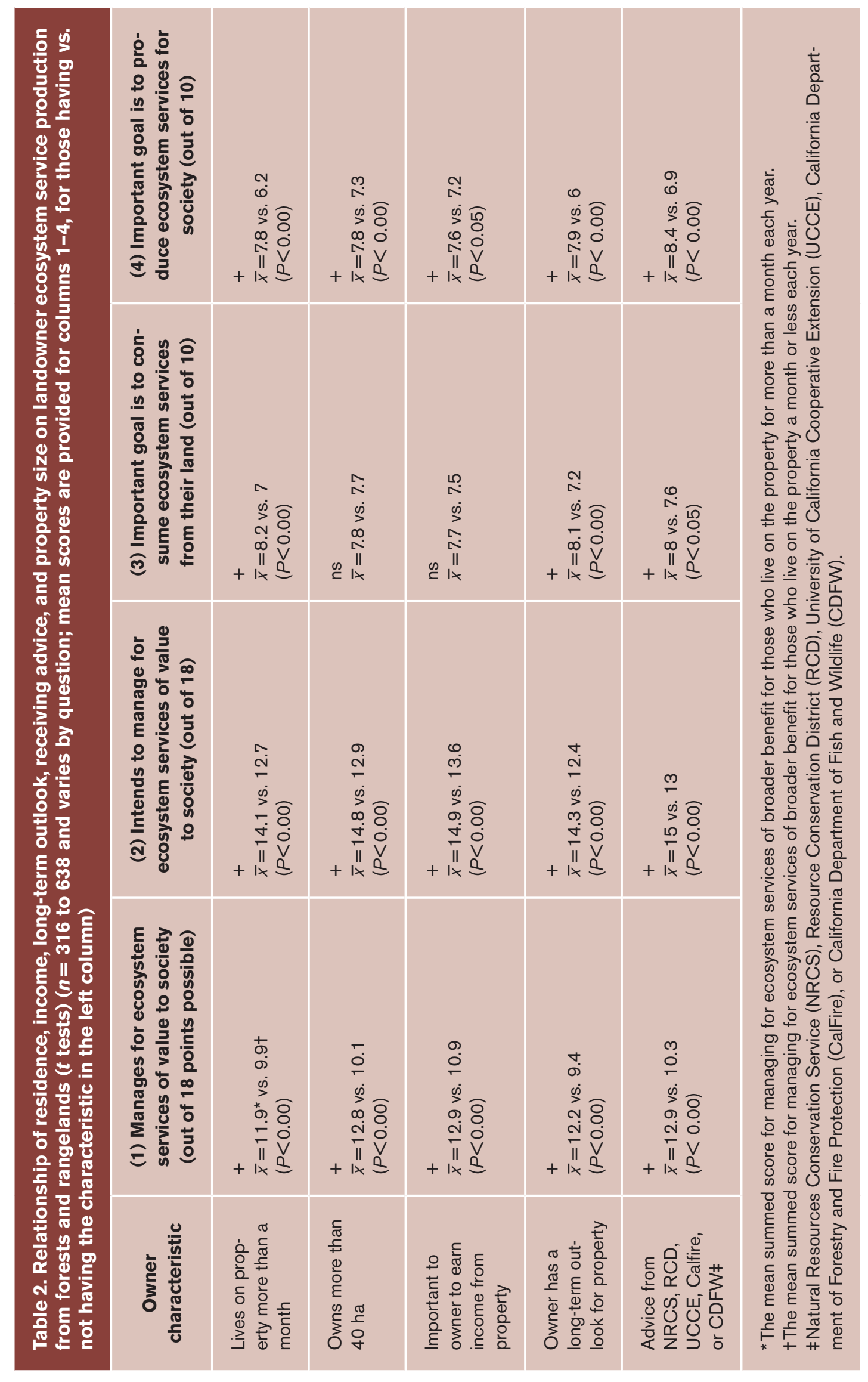


of landowners participating, and forest certification, with 4\%, are other market-based efforts to support ecosystem service production through value added products. These percentages seem small, but only some landowners had properties large enough, or with the right kinds of production (farm, range, or forest) to qualify for a given program. In contrast, focusing on hardwood rangeland properties larger than 8 ha, $46 \%$ were enrolled in the Williamson Act in $2005 .{ }^{8}$ Nearly $80 \%$ of the ranchers in the 2013 survey, which had a higher proportion of larger properties in it because in the general landowner population, ranchers tend to own larger properties, reported participating in the program. ${ }^{16}$ The total area of land influenced by these programs is clearly much larger than the proportion of total landowners participating makes it seem, as owners of small properties far outnumber owners with large properties.

\section{Conclusions}

Although the California forest and range landowner population is diverse in many ways, several themes emerged that are important for efforts to increase and sustain ecosystem service production from private lands. First, it is important to understand that private landowners are a diverse and changing group with a variety of goals and objectives for their lands. The number of smaller properties and amenity ownerships is increasing, with important implications for ecosystem service production. Owners of smaller properties are less likely to get advice from advisory organizations and other agencies or groups, and though owners with all property sizes value ecosystem services, those with larger properties are more likely to actively manage for them.

Advice from natural resource advisory agencies is related to management for ecosystem services. Landowners value information from advisory agencies, land trusts, or private consultants highly. They also tend to find these kinds of entities more acceptable as conservation partners and purchaser of ecosystem services than agencies that also have an enforcement or regulatory role.

Reaching absentee owners is a significant challenge and complicates prediction of future ecosystem service flows. Living on the property more than 1 month annually and having a long-term outlook for the property are strongly associated with active management for ecosystem service production, as is having a larger property and earning income from the land. Landowners are using a variety of sources for land management advice. Although most of the landowner characteristics reviewed here cannot be changed by outreach or policy, the amount and quality of information landowners get is something that can be influenced. About $11 \%$ of landowners received advice from land conservation organizations, $12 \%$ from land trusts, $20 \%$ from private consultants, and $22 \%$ from county fire departments. ${ }^{15}$ These studies make it apparent that landowners of all types need information from groups they are comfortable with, and that addresses production of the ecosystem services that they believe are important. Advisory services, including private consultants, professional organizations, agencies like the Natural Resource Conservation Service, and Cooperative Extension have a vital role to play in sustaining ecosystem service production.

\section{References}

1. Millennium Ecosystem Assessment. 2003. Ecosystems and human well-being: a framework for assessment. Washington, DC, USA: Island Press. 245 p.

2. California Department of Forestry and Fire ProtecTION (CALFIRE). 2010. California's forests and rangelands: 2010 assessment. Sacramento, CA, USA: Forest and Rangelands Assessment Program. 343 p.

3. California Department of Forestry and Fire ProtecTION (CALFIRE). 2003. Changing California: forest and range 2003 assessment. Sacramento, CA, USA: Forest and Rangelands Assessment Program. p. A-26. Available at: http:// frap.fire.ca.gov/data/assessment2003/Assessment_Summary/ appendix_300.pdf. Accessed 10 September 2014.

4. Huntsinger, L., And J. Oviedo. 2014. Ecosystem services may be better termed social ecological services in a traditional pastoral system: the case in California Mediterranean rangelands at multiple scales. Ecology and Society 19(1):8.

5. Sorice, M. G., U. P. Kreuter, B. P. Wilcox, and W. E. Fox III. 2014. Changing landowners, changing ecosystem? Landownership motivations as drivers of land management practices. Journal of Environmental Management 133:144-152.

6. Brown, D. G., K. M. Johnson, T. R. Loveland, and D. M. Theobald. 2005. Rural land-use trends in the conterminous United States, 1950-2000. Ecological Applications 15(6):18511863.

7. Ferranto, S., L. Huntsinger, C. Getz, G. Nakamura, W. Stewart, S. Drill, Y. Valachovic, M. Delasaux, and M. KeLly. 2011. Forest and rangeland owners value land for natural amenities and as financial investment. California Agriculture 65(4):184-191.

8. Huntsinger, L., M. Johnson, M. Stafford, and J. Fried. 2010. Hardwood rangeland landowners in California from 1985 to 2004: production, ecosystem services, and permanence. Rangeland Ecology E Management 63(3):324-334.

9. Walker, P., and L. P. Fortmann. 2003. Whose landscape? A political ecology of the 'exurban' Sierra. Cultural Geographies 10:469-491.

10. Gosnell, H., and J. Abrams. 2011. Amenity migration: diverse conceptualizations of drivers, socioeconomic dimensions, and emerging challenges. GeoJournal 76(4):303-322.

11. Huntsinger, L. 2009. Into the wild: vegetation, alien plants, and familiar fire at the exurban frontier. In: A. Esparza and G. McPherson [EDs.]. The planner's guide to natural resource conservation: the science of land development beyond the metropolitan fringe. Berlin, Germany: Springer. p. 133-156.

12. Wacker, M. J., And N. M. Kelly. 2004. Ranchers vs. ranchettes in California's oak rangelands: livestock grazing appears a viable - and useful-vegetation management tool in the Sierra Nevada foothills. Rangelands 26(2):17-22. 
13. Ferranto, S., L. Huntsinger, C. Getz, M. Lahiff, W. Stewart, G. Nakamura, and N. M. Kelly. 2013. Management without borders? A survey of landowner practices and attitudes towards cross-boundary cooperation. Society and Natural Resources $26: 1082-1100$.

14. Fortmann, L. P., and L. Huntsinger. 1989. The effects of non-metropolitan population growth on resource management. Society and Natural Resources 2(1):9-22.

15. Ferranto, S., L. Huntsinger, W. Stewart, C. Getz, G. Nakamura, and N. M. Kelly. 2012. Consider the source: the impact of media and authority in outreach to private forest and rangeland owners. Journal of Environmental Management 97:131-140.

16. Lubell, M. N., B. B. Cutts, L. M. Roche, M. Hamilton, J. D. Derner, E. Kachergis, and K. W. Tate. Conservation program participation and adaptive rangeland decision-making. 2013. Rangeland Ecology \&' Management 66(6):609-620.
17. Plieninger, T., S. Ferranto, L. Huntsinger, N. M. Kelly, and C. Getz. 2012. Appreciation, use, and management of biodiversity and ecosystem services in California's working landscapes. Environmental Management 50(3):427-440.

18. Cheatum, M. F., A. P. Casey, and B. Parkhurst. 2011. Payments for ecosystem services: a California rancher perspective. Washington, DC, USA: Nicholas Institute for Environmental Policy Solutions, Duke University. 74 p.

19. Dillman, D. A. 1975. Mail and telephone surveys: the tailored design method. New York, NY, USA: Wiley \& Sons. $464 \mathrm{p}$.

Authors are Graduate Student Researcher (Ferranto), Professor, buntsinger@berkeley.edu (Huntsinger), and Professor and Specialist (Kelly), Environmental Science, Policy and Management, University of California, Berkeley 94720, USA. 